\title{
Digital Single Market as an Element in EU-Georgian Cooperation
}

\section{Archil Chochia \\ Tanel Kerikmäe}

\author{
Tallinn Law School, \\ Tallinn University of Technology \\ Akadeemia tee 3 \\ Tallinn 12618, Estonia \\ E-mail: archil.chochia@taltech.ee \\ E-mail: tanel.kerikmae@taltech.ee
}

The current issue of the Baltic Journal of European Studies is partially dedicated to the topic of EU-Georgian cooperation. Tallinn Law School of the Tallinn University of Technology has recently successfully completed the project "Digital Single Market as a Key Element in EU-oriented Georgian Higher Education" with its Georgian partners. The project was funded by the Estonian Ministry of Foreign Affairs within Development Cooperation and Humanitarian Aid. Besides other achieved goals, the project also resulted in academic research articles, some of which are presented in this issue of our journal.

Digital single market (DSM) is one of the priorities of the European Union, while it is a relatively new field in many universities. The raison d'etre for DSM is to use digital economy as a tool for further integration that makes the research interdisciplinary and therefore relevant to different areas of study. The EU integration is a priority for Georgia — while Georgian higher education institutions have included more EU-related studies in their curricula, DSM is still not relevantly reflected in this process. The project aimed to use TalTech's experience in this field of studies to develop it in the leading Georgian law schools.

Tallinn Law School (TLS) has a long history of cooperation with Georgian law schools involved in the project. During these years more than 100 Georgian students have studied at TLS, with many of our alumni currently working in the public and private sector in Georgia. The universities have been cooperating in research and development activities, including curricula development 
and supervision of doctoral dissertations. TLS has hosted two Jean Monnet conferences on EU Eastern Partnership, in September 2015 in Georgia and in February 2016 in Estonia, where representatives of these Georgian schools were involved. Furthermore, head of the project Dr. Archil Chochia together with director of TLS Professor Tanel Kerikmäe recently published a book Political and Legal Perspectives of the EU Eastern Partnership Policy (Kerikmäe \& Chochia, 2016) and some co-authors of the chapters are representatives of these schools. During this cooperation the lack of information on a new key element of EU studies, such as Digital single market, in Georgia has been highlighted.

Based on this experience, it became evident that there is special interest on the Georgian side to improve expertise in the field of EU law, especially its new developments. Georgian Competition Agency has been established only recently (in April 2014 by government decree no. 288), therefore there was a great need of support in the form of sharing experience and establishment of partnership between them and their European colleagues. Such interest was also based on the state policy of Georgia who sees eventual EU membership as a priority. In 2004, Georgia created the Office of State Minister in European and Euro-Atlantic Integration and EU Integration Commission. The need for more knowledge in EU-related fields is state motivated not only for different institutions but also for universities in the country, due to the growing demand from students. In June 2014, the EU and Georgia signed an unprecedented Association Agreement, which included a Deep and Comprehensive Free Trade Area (DCFTA). The following developments make it even more important to raise the level of knowledge in Georgia concerning such fields as EU competition law and EU internal market law (Chochia \& Popjanevski, 2016).

Georgia has been a priority partner country for Estonia's bilateral development cooperation since 2006 (Kerikmäe et al., 2014). The project complied with two strategic priorities from Estonian-Georgian development cooperation priority areas for the period 2016-2018:

1) Improving the quality of education - as the project directly addressed the quality of education at leading law schools in Georgia, modernising their curricula and linking them to the country's EU aspirations.

2) Strengthening democratic state structures and systems-as the project involved Georgian Competition Agency, trained their representatives, helped them establish closer cooperation with Estonian Competition Authority, as well as strengthened their cooperation with Georgian law schools. 
The DSM is one of the main objectives of the European Union in ensuring that "economy, industry and employment take full advantage of what digitalisation offers". Implementation of DSM is based on several strategy documents and normative acts, and it is also a part of European Commission's Work Programme 2016. Rapid changes in acquis communautaire are not always expected by countries seeking European membership, which may slow down the effectiveness of the Europeanisation process. European Union enlargement process, as well as EU Eastern Partnership have not been adjusted to be in conformity with the recent ambitions of the Union. We, the undersigned believe that in this integration process, the new era of digitalisation should be better reflected in the European studies in potential candidate countries. There should also be a place for objective criticism of controversies in the process of targeting the aims of DSM (legal uncertainty in the field of copyright and cross-border data, for example). The DSM will cause radical change in business models and mindsets due to innovative cloud computing and smart grids. It is also relevant in the context of global competitiveness as large and growing economies such as China, India and the US are developing their digital markets as well.

Georgia, as one of the countries aiming for eventual EU membership, has an architectural plan for building an ICT-driven nation, supporting international cooperation in the field. Furthermore, orientation to ICT has been relatively well reflected in the curricula of Georgian higher education institutions; however, the EU legal developments in this field have not been addressed, which could result in the lack of specialists with expertise in EU DSM.

According to Georgian Government's Strategy 2014-2017 on information and communication related to Euro-integration (no. 1237), it is vital for Georgia to inform its citizens about the country's European integration process, as well as educate ordinary citizens and officials in EU-related fields. It is very important for Georgian partners to have access to additional training in the mentioned fields and up-to-date materials, as well as the possibility to share experience with European colleagues and establish long-term partnerships with them. Georgia has achieved sizable progress in its goal to become an ICT-driven nation, implementing several reforms and engaging in many cooperation projects with the leading countries in the field. Estonia, as one of the flagship Member States in the field, has been closely cooperating with Georgia, as there have been and still are several projects supporting the country to strengthen its e-Governance.

As the EU is based on the concept of the rule of law and the European integration process is strongly based on legal principles, norms and a common legal space, the aim of our project was in compliance with the aims of Georgian universities 
to reflect the new European legal paradigm in their study programmes and academic research activities. When the EU is criticised for being distant from the citizens and everyday life, the complex legal system is often mentioned as one of the main aspects (Särav \& Kerikmäe, 2016). Another challenge is the influence of digitalisation to the structure of law in general, when EU law in the field of digital market is moving towards a principle-based regulation and establishes new legal phenomena such as the e-identity of stakeholders and user centricity.

Accordingly, the process has to be considered when updating study programmes and setting up new research directions at higher education institutions. The most advanced Eastern Partnership country has great visions on e-Governance based on European values. However, judging by the feedback received from Georgian colleagues, the curricula at the local universities were outdated and did not always reflect the legal and economic perspectives related to development of DSM, while there was a lack of cooperation between Georgian and Estonian scholars in the field of EU studies in general. The project addresses all the issues indicated above and after two years of successful work, has resulted in different achieved goals, including academic research articles published in this issue and the focus on EU-Georgian relations in general.

\section{References}

Chochia, A. \& Popjanevski, J. (2016), 'Change of power and its influence on country's Europeanization process. Case Study: Georgia,' in T. Kerikmäe \& A. Chochia (eds.) Political and Legal Perspectives of the EU Eastern Partnership Policy, Cham: Springer International Publishing, pp. 197-210. https://doi.org/10.1007/978-3-319-27383-9_13

Kerikmäe, T. \& Chochia, A., eds. (2016), Political and Legal Perspectives of the EU Eastern Partnership Policy, Cham: Springer International Publishing. https://doi.org/10.1007/978-3-319-27383-9

Kerikmäe, T.; Nyman-Metcalf, K.; Gabelaia, D. \& Chochia, A. (2014), 'Cooperation of post Soviets with the aim of not being "post" and "Soviets",' in N. Šišková (ed.) From Eastern Partnership to the Association. The Legal and Political Analysis, Cambridge: Cambridge Scholars Publishing, pp. 144-159.

Särav, S. \& Kerikmäe, T. (2016), 'E-Residency: a cyberdream embodied in a digital identity card?' in T. Kerikmäe \& A. Rull (eds.) The Future of Law and eTechnologies, Heidelberg: Springer-Verlag, pp. 57-79. https://doi.org/10.1007/978-3-319-26896-5_4 